\title{
Facilitation of the Understanding of Novels by Senior Pupils as a Problem of Psycholinguistics
}

\section{Фасилітація розуміння старшокласниками літературних творів як психолінгвістична проблема}

\section{Nataliia Mykhalchuk ${ }^{1}$}

DSc. in Psychology, Professor, Head of the Department of Practice of English

\author{
Наталія Михальчук ${ }^{1}$ \\ доктор психологічних наук, \\ професор, завідувач кафедри \\ практики англійської мови
}

\author{
E-mail: natasha1273@ukr.net \\ https://orcid.org/0000-0003-0492-9450 \\ ResearcherID: A-9440-2019 \\ ScopusID: 57214227898
}

Natalia Hupavsheva ${ }^{2}$

Ph.D. in Psychology, Associate

Professor, Doctoral Learner
Наталія Хупавцева ${ }^{2}$ кандидат психологічних наук, доцент, докторант

E-mail: natalahupavceva@gmail.com

https://orcid.org/0000-0002-8883-7686

ResearcherID: AAC-2156-2019

${ }^{1}$ Rivne State University of the Humanities

12, Stepan Bandera Str., Rivne, Ukraine, 33000

${ }^{2}$ Pereiaslav-Khmelnytskyi

Hryhorii Skovoroda State

Pedagogical University

$\triangle$ 30, Sukhomlynskyi Str.,

Pereiaslav-Khmelnytskyi, Kyiv Reg.,

Ukraine, 08401
${ }^{1}$ Рівненський державний гуманітарний університет

$\bowtie$ вул. Степана Бандери, 12, Рівне, Україна, 33000

${ }^{2} Д В Н 3$ «Переяслав-

Хмельницький державний педагогічний університет імені Григорія Сковороди» $\triangle$ вул. Сухомлинського, 30, Переяслав-Хмельницький, Київська обл., Україна, 08401 


\section{ABSTRACT}

The purpose of the article is to identify main components of the activities of pupils in reading novels at the lessons of World and English literature at secondary school; to propose such types of dialogism, which will facilitate pupils' understanding of novels; to describe the results of our pilot study which was organized in September-December 2019 at secondary educational institution № 15 in $t$. Rivne at the lesson of English literature with the aim to analyze the types of dialogism in the process of reading and understanding a novel by pupils.

Methods and methodical instrumentation of the research. The following scientific methods were used: holistic analysis of the text, problem-thematic analysis, also comparative analysis (Bondarenko, 2016); the descriptive method, the method of distributive analysis, the method of syntactic transformation of text material (Voronkova, 2020).

The results of the research. Taking into account the features of senior children, we have identified three main components of the activities of pupils in reading novels at the lessons of World and English literature at secondary school. These components are: (1). A cognitive component, that has in its structure: a) contexual reading; (b) interpretive reading; (c) semantic reading. (2). A communicative component. (3). Subjectly-oriented component. We proposed such types of dialogism: (1). Subordinated dialogism, which involves taking into account the personality of the author of the text (or its heroes), which in this case is the subject of the novel. (2). Coordinative dialogism, which, unlike subordinated one, is oriented not so much to the personal aspect as to the procedural nature of interaction in the broad meaning. 3. Personality-reflexive dialogism which is the most meaningful in terms of understanding of the partner in the process of quasi-communication.

Conclusions. In general, senior pupils tend to focus on coordinative type of dialogism in the process of reading a novel, because, first of all, the procedural interaction between schoolchildren and the author of the novel is quite important for them. In order to actualize subordinate and personality-reflexive dialogism, in our opinion, senior pupils should be involved into the activity of translation of novels written in a foreign language (it is a translation from a foreign language into their native language).

Key words: understanding the novels, facilitation of understanding the novels, reading activity, a cognitive component, a communicative component, subjectly-oriented component, subordinated dialogism, coordinative dialogism, personality-reflexive dialogism.

\section{Introduction}

A novel is a central element of the scheme of a communicative act, which can be easily represented as a three-component structure: the author (the speaker) - the reader (the addressee). The first two 
elements of this scheme, used for the purpose of implementing any communicative act, are combined quite rigidly in a paradigm of literary creativity. This is explained, firstly, by the fact that the author seems to «pass» textual material through himself/herself, through the individualpersonal mental and emotional world. Secondly, unlike other types of texts which describe only a certain sequence of events, a novel is created gradually, by different stages (Bowerman \& Levinson, 2001; Gennari, Sloman, Malt \& Fitch, 2002). By the time, for example, a scientific article or a textbook, a note or a contract are written in a real life, there is already information that should be inside the content of these texts. In contrast, at the time of writing the novel of its content level does not exist, it appears simultaneously in the period of writing a novel by the author. The form of the artistic message and its content do not exist separately, and the creator of this unity is always presented in it (Delong, Troyer \& Kutas, 2014).

The novel is complex in its structure and multilayered. The main tasks of its analysis and interpretation, which largely lead to the process of its general understanding, is to understand the maximum of author's thoughts and feelings, to evaluate them, to substantiate and, on this basis, to build their own point of view according to this novel (Boroditsky, 2001; Gleitman \& Papafragou, 2005; Khyzhniak \& Liashov, 2019). The idea of the author is to be embodied into the context of the novel. In the scientific literature the principle of quasi-communication between the author and the reader is called «the principle of the funnel (or watering can)»: through its wide part into the consciousness of the addressee «flows» the whole author's world, and the reader has to reproduce maximally all the wealth of our reality, concentrated in the paradigm of this novel (Kukharenko, 2004: 11).

Ideally, according to V.A. Kukharenko (2004: 58), the wide sides of both funnels should be absolutely identical. However, due to the mandatory inclusion into this scheme of the input and the output of two different persons, the predicted complete coincidence of the funnel's sides does not occur. The reader continually incorporates his/her life experience into the process of analyzing and understanding the novel. In this case the novel remains unchanged. Also, the signals that are objectively presented in it and caused different emotions, feelings and associations of the addressee have not been changed. But each reader is aware of only some pieces of the information from the whole novel. 
This is because our perception is always selective. Psycholinguists (Aleksandrov, Memetova \& Stankevich, 2020; Elahi Shirvan, Khajavy \& MacIntyre, 2019; Lucy, 2010) have pointed out the selective character of the person's perception because of the different varieties of the qualities of the object, and, in such a way, a person fixes his/her attention on the main (from his/her point of view in this or that situation) and builds his/her own scale of assessments and his/her behavior, based on these characteristics. Something similar happens in the process of perceiving an artistic object, we mean the novel, that naturally influences our understanding of the context (Hu \& Liu, 2019).

Thus, the mechanisms of interaction between the author and the reader are to some extent programmed by the author of the novel; they are reflected in the structure of it. The author initiates a dialogue with a reader and reproduces his/her own intentions in an intersubjective sign form. Understanding the novel, the reader reveals the idea of the author, realizes the true meaning of the deep layers of the context, as if repeating «the path» the author «has walked», to some extent even reproduces the creative individuality of the author's person, and, at the same time, completely transforms, reflects, restructures the reality reflected by the narrator (Kalmykova, 2016; Myachykov, Garrod \& Scheepers, 2012).

Let us analyze the basic scientific approaches to the characteristics of a novel.

Psycholinguistics is based on the understanding of a novel from a philological point of view. Philologists mean a novel as a closed system with a complex internal organization, all elements of which are in close interaction (Jackendoff, 1983; Wallentin, Rocca \& Stroustrup, 2019). Characteristic features of the novel are completeness, which is objectified in a form of a written document, literary editing in accordance with the requirements of this type of document, and structural completeness of the text, which implies the presence of a number of special units, united by different types of lexical, grammatical, logical and stylistic meaning. These units have a definite purposefulness and pragmatic meaning (Athanasopoulos, Bylund, Montero-Melis et al., 2020).

Creating a novel, the author repels from certain real facts, summarizes them in his/her reasoning, sometimes even formulates an abstract conclusion (Fodor, 1975). In such a way aesthetic images are simulated, which can be called generalized (or typed, synthetic) due to 
the nature of their creation. Their development and interaction form the structure of a novel (Kesebir, 2017). The aesthetic images are formed on the basis of verbal (pronounced by speech forms, models or patterns) images which are localized within a context of the novel (Kalmykova \& Kalmykov, 2015).

For Psycholinguistics it is also important the description of the levels of organization of a novel from a linguistic point of view. The first level is a phonographic one. At this level a great importance is emphasized on the sound imagery and sound symbolism, sound repetitions (alliteration, assonance), actualization of verbal emphasis of lexical units (Wolff \& Holmes, 2011).

The next, the second level of a novel is morphemic. If the unilateral unilateral linguistic unit, which is a phoneme, is capable of updating under special conditions of its functioning, becoming a facilitator of additional information of a novel, we can assume that a morpheme, a unit of the next level, which has not only a form but also its own content, contributes even more a significant nuance in creating a deeper sense of the text. In addition to the logical and emotional emphasis, which is the most expressive of the author's modality, morphemic repetition in a great degree rhythmizes expression, and it is therefore often used in balanced structures, such as antithesis, parallelism and enumeration (Boroditsky, 2011; Lucy, 1996).

The next, more complicated level of a novel is lexical. At this level compositional retardation plays a significant role in understanding the text, which, like other types of retardation, creates some tension in the paradigm of the text. In such a way, the repeated repetition of the pronoun together with use of emotionally-evaluative words provides a corresponding author's conceptual evaluation (Papafragou, Hulbert \& Trueswell, 2008). Here is the example from V. Hugo's novel «NotreDame de Paris»:

«Эти красавищы девушки, с их ядовитыми и злыми язычками, извивающиеся, скользящие, суетящиеся вокруг уличной плясуньи, представляли собою зрелище, достойное более тонкого зрителя, чем Феб. Эти грачиозные создания были бесчеловечны... Они напоминали борзых на охоте... Они нисколько не считались с её присутствием и вслух говорили о ней как о чём-то неопрятном, ничтожном, хотя и довольно красивом» (Hugo, 2003: 228). 
The use of the prepositional pronoun «these» together with emotionallyevaluative words is perceived by the reader as a negative-evaluative attribute. With the pronoun «they» V. Hugo not only confirms the negative evaluation of the previous statements, but also intensifies them by repeating.

And finally, the next level of a novel is syntactical one. The basic syntactical unit is a sentence. The sentences of literary language are constructed according to rather rigid norms, and the author, of course, tries to adhere to these norms. However, the normative characteristics of a novel are overlaid with individual author's peculiarities of style, as well as additional expressive, compositional, thematic and other tasks, due to the specific nature of artistic speech (Fuhrman \& Boroditsky, 2010; Kuperberg \& Jaeger, 2015). The combination of these three factors creates a complete syntactic picture of a particular artistic text. Therefore, reading a novel the most difficult for the addressee is to identify the aesthetic significance which the syntactical characteristics of the text contribute to its general expression (Stutterheim \& Nüse, 2003).

The length of the sentence also significantly influences the semantic (thematic), compositional and stylistic characteristics of a novel. The length of the sentence is the actualizer of the expression, which creates the additional meaningful and expressive capacity of the novel. At the syntactical level of a novel its understanding is greatly influenced by intonation and punctuation (Jiang, Jong \& Tse, 2020).

A psycholinguistic view on the process of understanding the novel, compared with a linguistic one, is characterized by a greater understanding by a reader the boundaries of the text itself, which are presented both as a product and the means of accomplishing a communicative task that arises simultaneously between the participants of the communicative act - the narrator (the author) and the addressee (the reader). Each of them develops his/her own pragmatic attitudes, one of them has an adequate transfer of information, the other has an adequate understanding of it. The collision of these preferences defines the meaningful structure of the text and the hierarchy of its components that make up this structure, which makes the text a tool of communication (Shtyrov, Kirsanov \& Shcherbakova, 2019; Khmil \& Popovych, 2019).

Psycholinguists pay considerable attention to a form of a novel, that, in their opinion, significantly influences the reader's understanding 
of the text. A deep analysis of the views of scientists on the features of adequate understanding of novels we find in a lot of scientific articles (Kesebir, 2017; Rubskyi, 2019).

A novel is characterized by A.A. Brudnyi (1975) as the paradigm that arose from the combination of characters had been addressed to the reader. As a rule, a novel appears in a form of a compact expression of a certain content, which is expanded in time and makes some sense. Such a meaning, in turn, should be accessible to the understanding of a certain range of readers (the researcher takes into account the readers' age, their education, fields of professional activities, etc.). The scientist proposes the following scheme of the analysis of a novel: (1) according to a view of the analysis of the reality; (2) in a view of the individual characteristics of people for whom this novel was created and who need to understand it (therefore, the form of expression plays a major role); (3) according to the indirect characterization of the author of the novel (the nature of his/her thoughts, in what manner the narrator expressed feelings, how and for what reasons the story had begun, etc.). In such a context a novel provides some information about its author, and this, in turn, helps to understand the meaning of the text more deeply.

When analyzing a novel, the reader usually thinks about: (a) the relationship of this text with other novels; (b) the specific circumstances of writing the novel and the peculiarities of its understanding by the reader (his/her locally-temporal plan).

A.A. Brudnyi emphasizes two-sided nature of understanding a novel. From the moment we become aware that it is a novel, when we understand or try to understand it, we proceed from the fact that, on the one hand, the novel is a simulated reality, oriented towards what it should be understood, and, on the other hand, any novel retains the important feature of the objective reality - it is the material medium of the content given to us by the way of sensory perception that is independent of our will and consciousness. Therefore, inside novels there are compatible categories, such as immutability of the «material carrier» of sense with the change of the meaning itself in the process of reading activity. Thus, A.A. Brudnyi concludes that the characteristics of a novel include two factors: the text itself and non-textual categories, which are the author of the text and the reader (Brudnyi, 1975: 117).

The purpose of the article is to identify main components of the activities of pupils in reading novels at the lessons of World and English 
literature at secondary school; to propose such types of dialogism, which will facilitate pupils' understanding of novels.

\section{Methods and methodical instrumentation of the research}

The following scientific methods were used as the basis of the research: holistic analysis of the text, problem-thematic analysis, also comparative analysis (Bondarenko, 2016).

The following methods have also been used to study the research material: the descriptive method - in order to distinguish units that denote the category of the monologue statement of pupils; the method of distributive analysis - for dividing the selected units (secondary segmentation) into such word forms with the purpose of their analysis, classification and interpretation for the usage of the data obtained during the formal description of the structures that denote the category of dialogism; the method of syntactic transformation - to identify those features of the structures of dialogism's categories that are not explicitly available in the analyzed sentences, having been translated by pupils (Voronkova, 2020).

\section{Participants}

In our article we described the results of our pilot study which was organized in September-December 2019 at secondary educational institution № 15 in t. Rivne at the lesson of English literature with the aim to analyze the types of dialogism in the process of reading and understanding a novel by pupils. 532 pupils of $8-9$ forms were participated in our research.

\section{The Results of the Research and their Discussion}

We think that the reading activity contains cognitive and communicative components. At the same time, obtaining the content and characteristics of pedagogically regulated reading activity, we took into account the basic concepts of the theory of axiological psychology of the person (Karpenko, 2009). Therefore, we mean pedagogically regulated 
reading activity as one that is able to create the most positive conditions for the development of the axiopsychic of the person of senior pupils.

Axiopsychics contains various components of the value-semantic sphere of the person, such as: motivational (subjective, mental, semantic) attitudes, dispositional formations (social attitudes and value orientations), motivational factors, emotional-value characteristics of the process of experience (Karpenko, 2009). In our opinion, a senior pupil with a well-formed axiopsychic is able to take the position of so-called polysubject - a person with a high level of the development of value consciousness, capable of moral self-determination. Thus, pedagogically regulated reading activity, to our mind, facilitates the formation of the individual image of the world of senior pupils, achieving them a high level of personal development, at which they are able to selfdevelopment of their knowledge on the basis of the formed system of values and meanings. In this case, the transcendental value of the reading activity of senior pupils will be achieved through the combination of cognitive, communicative and subject-oriented components, which, in turn, will actualize the motives of the activity, meaningful constructs and attitudes, meaningful dispositions. All these processes also facilitate the formation of pupils' personal meanings, which are included in the components of the text. This, on the one hand, will determine the active self-development of senior schoolchildren in the reading activity, the formation of the value-semantic sphere of their person, and, on the other hand, allows us to consider the reading activity as a psychologicalaxiological process. In this way, the reader's activity (whether pedagogically regulated or self-organized) will help to make a senior pupil an active subject of axiogenesis. The latter, through its quasicommunication with the author and the heroes of the novel, will be included into the spiritual world of the Other person as an empowered partner, bearer of Truth and a Possible Model of Self-development. All these factors put a pupil more closer to the transcendental spiritual subject with formed axiopsychics.

Taking into account the features of senior children, we have identified three main components of the activities of pupils in reading novels at the lessons of World and English literature at secondary school. These components are:

(1) A cognitive component, that has in its structure: (a) contexual reading; (b) interpretive reading; (c) semantic reading. 
(2) A communicative component. It consists of: (a) the process of quasi-communication of the author of the novel and the reader, facilitating the actualization of the personal experience of the latter; (b) the pupil's orientation toward co-creation with other readers and understanding the awareness of feedback; (c) the transformation of the content of a novel, that facilitates its interpretation based on deep understanding of the text's context.

(3) Subjectly-oriented component, which is based on: motivation of pupils' activity in reading novels; (b) the development of one's own vision of one's position at the level of forming the reader's personal meanings; (c) the ability to bring the reader's own personal meaning into the interpretation of the text; (d) the ability to perceive the point of view of another subject according to the process of reading a novel; (e) opportunities of the reader to transform his/her own understanding of a novel into the artistic structure, for example, into the form of a poetic message.

Dialogical content of cognitive, communicative and subjectlyoriented components of the reading activity of senior pupils will largely depend not only on the pupils' ability to analyze and to interpret the novel, but also on the dialogical interaction of schoolchildren with each other and a teacher, to organize or participate in discussions, disputes and productive communication at the lessons. We have formulated such types of dialogisms, which facilitate a teacher of World and English literature to organize effective dialogic interaction between the subjects of the educational activity. All these factors provide deeper understanding of novels by senior pupils. So, we proposed such types of dialogism:

(1) Subordinated dialogism, which involves taking into account the personality of the author of the text (or its heroes), which in this case is the subject of the novel. So, a pupil takes into account the position, thoughts, views of the author of the novel or its heroes. Thus, a subcomponent of subordinated dialogism is a subject-oriented one, that emphasize on the perception of a certain content of another person's message, which, unfortunately, often leads to subordination according to another person, uncritical agreement with his/her thoughts, ideas, etc.

(2) The next one is coordinative dialogism, which, unlike subordinated one, is oriented not so much to the personal aspect as to the procedural nature of interaction in the broad meaning. The main place here is paied on the content of dialogical reactions, their 
sequence, interdependence and complementarity. Coordinative dialogism assumes a subjective-discursive component as a rational justification by a pupil his/her point of view, at the same time - a tolerant attitude to the thoughts of the author or the heroes of the text in the process of quasi-communication with it. We mean that indispensable dominant is undoubtedly pupil's own hypothesis, position, opinion, etc.

(3) Personality-reflexive dialogism which is the most meaningful in terms of understanding of the partner in the process of quasicommunication. Subjectivity in the case of personal-reflective dialogism is a determinant of the development of pupils' own vision of his/her position, which implies the development of schoolchildren's critical attitude to their point of view and the position of the partners in the process of quasi-dialogical interaction, the ability to understand and comprehend the partner's statements in quasi-communication (for example, if the author of the novel is a partner in the process of quasidialogical interaction). In such a way a pupil has to justify his/her own judgments, to ask questions, to formulate doubts, to propose new ideas and suggestions, to express unconventional, original thoughts, to correct the statements of other participants in real conversations using such ideas which are acceptable at the same time.

All other substructures of dialogism - the associative one, the imaginative substructure and the expressive one - may in one way or another one relate to systems of coordinative, subordinative and personality-reflexive dialogism.

The functional interconnection of semantic structures in the process of reading activity of senior pupils is presented by Fig. 1.

In general, senior pupils tend to focus on coordinative type of dialogism in the process of reading a novel, because, first of all, the procedural interaction between schoolchildren and the author of the novel is quite important for them. Here are some examples of monologues given by pupils of 9-A form of a secondary educational institution № 15 in t. Rivne at the lesson of English literature (the theme is: "The novel «The Adventures of Oliver Twist» by Charles Dickens»). Our pilot study was organized in September-December 2019; the subject «English literature »" is taught as a discipline for pupils' and their parents' choice in classes with complicated studying a foreign language).

Mikle N.: «The Adventures of Oliver Twist» or «Oliver Twist» is one of the most famous novels by Charles Dickens. It's a classic rags- 
to-rich story about the orphan who has to find his way through a city full of criminals, and has to avoid being corrupted. But it wasn't just the lack of punch that caused contemporary readers to the object.

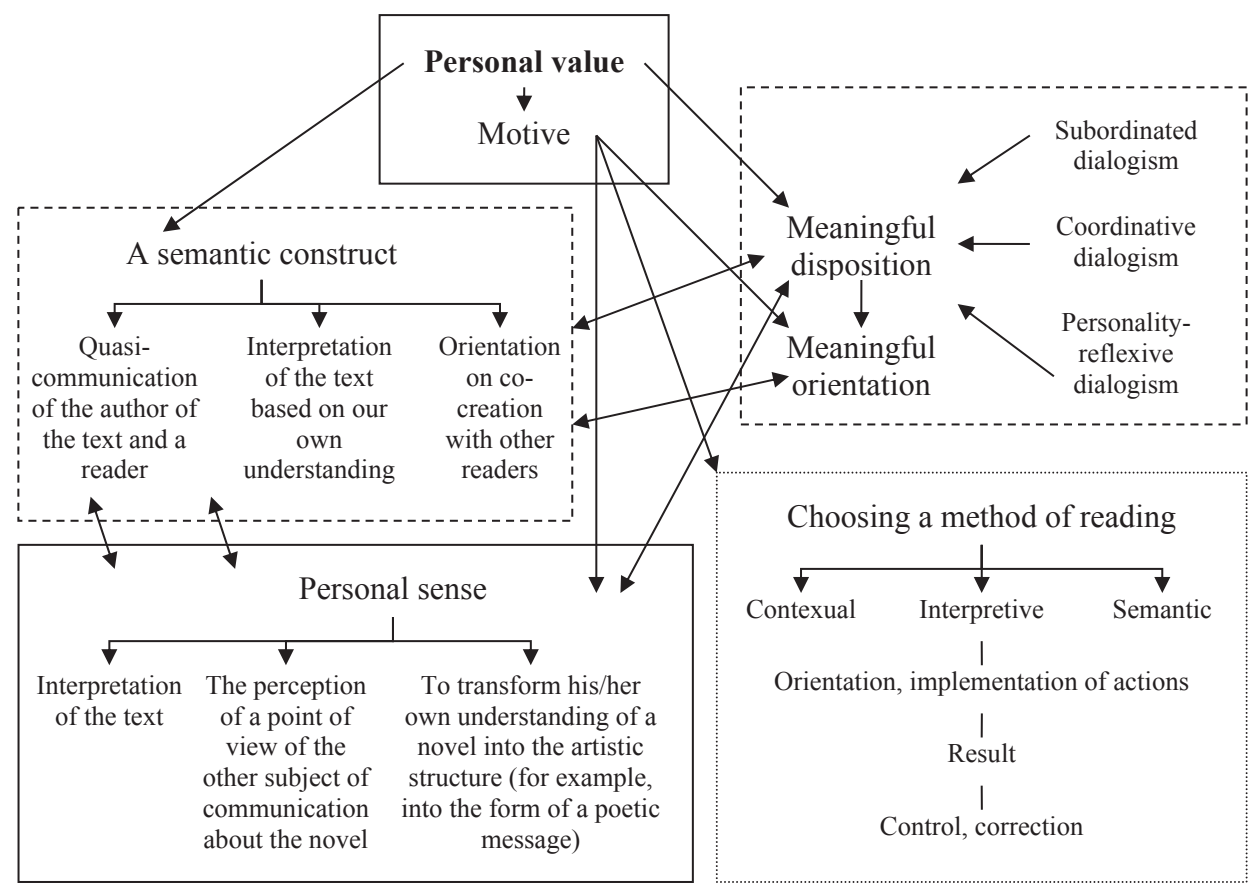

Fig. 1. The functional interconnection of semantic structures in the process of reading activity of senior pupils

Symbols:

....... - a cognitive component of reading activity

_ - subjectly-oriented component of reading activity

_ _ - - a communicative component of reading activity

«Oliver Twist» is the example of the style of the novel that was incredibly popular (but widely criticized) from the 1820 s to the $1840 \mathrm{~s}$ by the «Newgate novel». The «Newgate novel» takes its name from the Newgate prison, the main prison for felons (pickpockets, thieves, prostitutes, and murderers) in London. The famous criminals (Charles Manson and Scott Petersons of this time) had little pamphlets written about them which were handed out at their execution. These pamphlets, with the lives of criminals and their last words, were collected and published in one big volume called the «Newgate Calendar». Some 
writers read the criminal biographies and got ideas for their own novels. In «Nicholas Nickleby» we have the description of the prison, called Newgate: «The reality is rather different, but by no means to be despised notwithstanding. There, at the very core of London, in the heart of its business and animation, in the midst of a whirl of noise and motion: stemming as it were the giant currents of life that flow ceaselessly on from different quarters, and meet beneath its walls: stands Newgate; and in that crowded street on which it frowns so darkly - within a few feet of the squalid tottering houses - upon the very spot on which the vendors of soup and fish and damaged fruit are now plying their trades - scores of human beings, amidst a roar of sounds to which even the tumult of a great city is as nothing, four, six, or eight strong men at a time, have been hurried violently and swiftly from the world, when the scene has been rendered frightful with excess of human life; when curious eyes have glared from casement and house-top, and wall and pillar; and when, in the mass of white and upturned faces, the dying wretch, in his all-comprehensive look of agony, has met not one - not one - that bore the impress of pity or compassion». The critics believed that «Oliver Twist» and other Newgate novels were the factors which were damaging English morals. Because these novels didn't shy away from depicting criminal stuff - prostitution, stealing and even murder - critics said that reading those novels would desensitize people to violence. «Oliver Twist» is Dickens' only novel that is qualified as a «Newgate novel», though it seemed that he had just wanted to try his hand by the popular style of writing before turning to other, loftier pursuits.

In the novel «Oliver Twist» Dickens vigorously attacks the Poor Laws of 1834, showing the resulting brutal treatment of the poor. The workhouse system was designed to save money; by making the workhouses repellent places of starvation and hard labour the authorities intended to make hard work outside the workhouse seemed like a better choice and thus prevented able-bodied people from becoming what we called now «welfare abusers». By lessening the number of people who took public assistance, the authorities could save a great deal of money. However, they went too far in their emphasis on money over humaneness, as the author showed. Dickens ironically writes:

"[The system of starving the poor] was rather expensive at first, in consequence of the increase in the undertaker's bill, and the necessity of taking in the clothes of all the paupers, which fluttered loosely on 
their wasted, shrunken forms, after a week or two's gruel. But the number of workhouse inmates got thin as well as the paupers; and the board were in ecstasies» (Dickens, 1991: 34).

«Oliver Twist» considers to be a social novel. As the early example of the social novel, the book calls the public's attention to various contemporary evils, including child labour and the recruitment of children as criminals. Dickens mocks the hypocrisies of the time by using sarcasm and dark humour in dealing with the novel's serious themes.

The importance of «Oliver Twist» as a crusading work of art (hoping to show the difficult circumstances with which the poor in Dickens's time had to live) should not be underestimated. It is certainly an excellent work of art, but it is also a testament to the hopes for a better, more enlightened age. Dickens' delightful story «Oliver Twist» is a considerable achievement. Funny and incredibly sad, the novel is complete in all its aspects. «Oliver Twist» is a powerful indictment of the times in which the novel was written.

The next example is a monologue statement said by Oksana F. It is also the example of the actualization of coordinative dialogue in terms of understanding a novel by senior pupils.

Oksana F.: «The narrative structure of «The Adventures of Oliver Twist» differs from the novel «Bleak House». It is told by the thirdperson narrator and is much simpler. This type of narration is called the limited omniscient, as the author is the only one possible narrator.

The third-person narrator in the novel assumes the points of view of various characters in turn. The narrator's tone is not objective; it is sympathetic to the protagonists and far less so to the other characters of the novel. When dealing with hypocritical or morally objectionable characters, the narrative voice is often ironic or sarcastic. The author speaks in the past tense, in a sentimental, sometimes ironic, hyperbolic tone.

It is really important to comprehend the narrator in «Oliver Twist», as it is the main means for understanding the characters. In every chapter Dickens initiated a lengthy discussion of how the plot is working, or what he's planning on doing in the particular chapter (we can notice this especially clearly at the beginning of the chapter). This peculiarity can create the effect of reading a newspaper expose 
on criminals in London, instead of a novel. To confirm this we turn attention to Chapter 15:

"If it did not come strictly within the scope and bearing of my longconsidered intentions and plans regarding this prose epic... to leave the two old gentlemen sitting with the watch between them long after it grew too dark to see it... I might take occasion to entertain the reader with many wise reflections on the obvious impolicy of ever attempting to do good to our fellow-creatures where there is no hope of earthly reward... But, as Mr. Brownlow was not one of these... I shall not enter into any such digression in this place: and, if this be not a sufficient reason for this determination, I have a better, and indeed, a wholly unanswerable on, already stated; which is, that it forms no part of my original intention to do so» (Dickens, 1991: 167).

These digressions or breaks in the story remind the reader that this is a novel but not a real life. They serve the author to add the distance between us, between $\mathrm{Ch}$. Dickens and the readers, and the characters and the actions are real in the story. The distance between the reader and the characters in the novel was important to Dickens from the ethical and artistic point of view. Many of his contemporary critics and reading public feared that novels could be too realistic, and that's why readers wouldn't be able to show the difference between a fiction and the reality. «Oliver Twist» touched upon «dangerous» subjects like poverty, crime and the relationship between these all things. Thus Dickens probably felt that it was prudent to put the occasional check on the reader's sympathetic identification with the characters.

Throughout the novel, Dickens employs a shifting narrative voice. It is impossible to define the characteristics or moral position of the narrators in this novel, for they are continually shifting. At times when the narrator is detached and wordy, as in the opening paragraph, in which he says abstractly that he will not name the town or workhouse where a certain «item of mortality» was born. At the same time, he is mocking by the conventions of many novels of his time, which are opened with a lengthy and often smug description of the main character's birthplace and his/her family.

The anonymous narrator in the novel doesn't consistently stay in this remote but sarcastic voice, but sometimes shifts to remark ironically by supposedly wonderful way in which the poor are treated and because of any kind it is; or sometimes the narrator appeals to the 
friendly feeling of the reader. For example, we all know how chilled and desolate the best of us will sometimes feel. We can never count on being in any single relationship with the narrative voice for a long period of time. Just in such a way we relax. We are pushed away.

"We come to the conclusion that the narrative structure of «The Adventures of Oliver Twist» is limited omniscient. It is characterized by the shifting narrative voice. The third person narrator speaks in the past tense. The narrative tone is not objective; it is sentimental, sometimes ironic and hyperbolic».

The examples we have given testify about a deep understanding of a novel of art at the level of coordinative dialogism. This type of dialogism actualizes psycholinguistic characteristics of the novel in a quite simple way, and the status of pupils' understanding of the novel is quite approximate to the status of semantics and syntax. The pragmatic component of psycholinguistics appears to be embedded into the structure of the theory of Grammar theory, which indicates that the understanding of the text becomes a largely formalized process.

In order to actualize subordinate and personality-reflexive dialogism, in our opinion, senior pupils should be involved into the activity of translation of novels written in a foreign language (it is a translation from a foreign language into their native language). Then macrostructures of understanding the text are at the forefront as the units of global discourse coherence, the semantic and pragmatic content of these categories, which also form different types of discourses. Macrostructures include semantic macrostructures as unities about the positional content of texts (discourses) and pragmatic macrostructures as coherent sequences not of sentences, but of speech acts in which, as we know, the most significant element is a human factor. This factor plays so called illocutionary role. These macrostructures, in turn, actualize subordinate and personality-reflexive dialogism in the process of understanding the novel by senior pupils.

When we tell about understanding by senior pupils the novel written in a foreign, non-native language, the problem becomes much more complex than understanding a novel written in Ukrainian. In this context, it is worth to mentione the theory of M.M. Bakhtin about the interaction of the language, a speech and a person. This theory is based on the suggestion of the "Other Person» who, in this context, is the Translator (or the person who is translating the novel). It is known that 
the addressee actively influences the processes of speech generation, its vocabulary and stylistic features. According to M.M. Bakhtin, the addressee is located «inside» each author (or the addressee is co-author of translated novel; in this context, the role of the co-author is performed by the person who is translating a novel). Thus, this constant co-author of the reader's activity, or even the co-author of our consciousness, determines not only its content, but also the choice of content itself, and also influences the emotional evaluation of the context. In other words, the Other Person determines many factors of psycholinguistic pragmatics of expression the sentences. It is also possible for the imaginary addressee to act as a determinant of the production of a speech context that sets clear boundaries for internal dialogues. The sense of a dialogue is in the process of understanding, as M.M. Bakhtin says, a switch of cultural, personal and ethnic codes; therefore, the author invites us «to listen» and «to hear» the polyphony of different cultural spheres, but not simply concentrate on the polyphony of voices (Bakhtin, 1975).

Therefore, in order to actualize the subordinate and self-reflexive dialogism in the process of understanding the novels by senior pupils during our pilot experiment, we suggested schoolchildren to translate fragments of the novel «Cat's Cradle» by Kurt Vonnegut (2009). The professional translation of this novel, made by the translator A. Nemirova (Vonnegut, 2016), was offered to pupils for review and comparison immediately after they made their own, author's translation. In this article we'd like to offer the examples of the translation of fragments of Kurt Vonnegut's «Cat's Cradle» by senior pupils (with the aim of better perception of different variants of translation we'll present the translation done by A. Nemirova at the same time as we showed the translation of pupils).

«Nothing in this book is true» (Vonnegut, 2009: 7).

«Нічого немає правдивого в ичій книжиі» (Larysa O., 9-A form). «Німзо в цій книзі не правда» (Vonnegut, 2016: 8).

"Live by the foma* that make you brave and kind and healthy and happy» (Vonnegut, 2009: 9).

«Живи як фома, яка робить тебе хоробрим і добрим, здоровим i щзасливим» (Olga K., 9-A form).

«Живи безпечно, тому щзо тебе ие робить хоробрим, добрим, здоровим та щзасливим» (Vonnegut, 2016: 9). 
«We Bokononists believe that humanity is organized into teams, teams that do God's Will without ever discovering what they are doing. Such a team is called a karass by Bokonon ... "If you find your life tangled up with somebody else's life for no very logical reasons», writes Bokonon, «that person may be a member of your karass». At another point in The Books of Bokonon he tells us, «Man created the checkerboard; God created the karass». By that he means that a karass ignores national, institutional, occupational, familial, and class boundaries. It is as free form as an amoeba» (Vonnegut, 2009: 11).

«Ми Боконісти віримо, що людство складається з команд, які виконують волю Бога, і ті команди нікому не зрозумілі, тому щзо невідомо щзо вони творять. Така група називається Карассо бо Боконон ... «Якщо ви зрозуміли, щуо ваше життя заплутане 3 чужим життям $i \in$ не дуже логічним», пише Боконон «то особа може бути членом вашого Карассо». В іншому місці книги, Боконон говорить нам: «Людина створила шахову доску, а Бог створив Карассо». I Карассо означає те, щзо воно ігнорує національні, організачійні, професійні, сімейні та класові кордони. Воно як у вільній формі, як амеба» (Max G., 9-A form).

«Боконісти вірять, щзо народ складається з команд, які виконують Божу волю, $i$ ті команди мало кому зрозумілі, тому щуо вони не зрозуміло щуо роблять. Таку групу називав Боконон під назвою Карассо ... «Якщуо ви раптом зрозуміли, щчо ваме життя досить важке та переплітається з чужим життям $i \epsilon$ не дуже логічним», пише Боконон «то людина може бути головним вашого Карассо». В іншому місці книги, Боконон говорить нам: «Людина створила шахову доску, а Бог створив Карассо». Карассо означає те, щзо воно ігнорує національні, організащійні, професійні, сімейні та класові кордони. Воно як у вільній формі, яке з часом змінюється або пересувається до певних своїх причин» (Vonnegut, 2016: 12).

"All of the true things that I am about to tell you are shameless lies» (Vonnegut, 2009: 13).

«Всі справжні речі, які я збираюся розповісти Вам безсоромна брехня» (Vadym M., 9-A form).

«Всі иі речі, які я Вам буду розповідати є непристойною брехнею» (Vonnegut, 2016: 14). 
«Anyone unable to understand how a useful religion can be founded on lies will not understand this book either. So be it» (Vonnegut, 2009: 17).

«Людині, не зрозуміти, користі релігія, яка не може бути заснована на брехні, і вона не зрозуміє июю книгу теж. Нехай буде так»» (Nataliia Sh., 9-A form).

«Людина ніколи не зрозуміє ияю книгу, якщо не зрозуміє користі релігї яка заснована на брехні. Будь щуо буде» (Vonnegut, 2016: 19).

«Ladies and Gentlemen, I stand before you now because I never stopped dawdling like an eight-year-old on a spring morning on his way to school. Anything can make me stop and look and wonder, and sometimes learn. I am a very happy man. Thank you» (Vonnegut, 2009: 20).

«Леді $і$ джентльмени! Я стою тут, перед вами, бо все життя я озирався на всі боки, як восьмирічний хлопчисько весняним днем по дорозі в школу. Я можу зупинитися перед чим завгодно, подивитися, подумати, а іноді чогось навчитися. Я дуже щуаслива людина. Дякую вам» (Ostap R., 9-A form).

«Пані та панове! Я стою перед вами, тому щзо я завжди, точніше все життя я озирався на всі боки, як восьмирічний хлопчисько по дорозі до школи. Я можу зупинитися тодi, коли я хочу, $i$ перед чим завгодно, подивитися, подумати, навчитися. Я щзасливий. Дякую» (Vonnegut, 2016: 22).

«[It] was about the end of the world in the year $2000 \ldots$... It told how mad scientists made a terrific bomb that wiped out the whole world. There was a big sex orgy when everybody knew that the world was going to end, and then Jesus Christ Himself appeared ten seconds before the bomb went off» (Vonnegut, 2009: 23).

"[Це] було про кінець світу в 2000 рочі ... Він розповів, як божевільні вчені зробили приголомшливу бомбу, яка знищила б весь світ. Були великі оргї, коли всі знали, щзо світ йде до кінця, а потім, Ісус Христос з'явився за десять секунд до того коли вибухнула бомба» (Galyna V., 9-A form).

«Роман описував кінець світу в 2000 рочі. Там описувалося, як психопати вчені зробили жахливу бомбу, стерши все з лиця землі. Коли люди дізналися, що скоро кінещь світу, вони влаштували жахливу оргію, а потім, за десять секунд до вибуху, з'явився сам Icyc Христос» (Vonnegut, 2016: 25). 


\section{Conclusions}

If we analyze the translations offered by senior pupils and compare them with the translation of a professional interpreter (Vonnegut, 2016), we'll see that the translator A. Nemirova, as a rule, understands the novel of at the level of personality-reflexive dialogism, which is the most profound in terms of the content in the process of understanding the author of the text (or the partner of quasi- communication). The subjectivity of the translator in this case is a determinant of the development by A. Nemirova the vision from the position of the person, which is confirmed not only by a deep structural and functional analysis of the novel, but above all by the author's position in understanding the context, the perception of the novel from the perspective of the Subject in a quasi-communication process. The latter is also largely explained by the fact that the situational models of quasi-communication with the author of the novel not only show some stereotypical events or situations, but imply personal knowledge of native speakers, their feelings, willpower, etc.

Senior pupils, unlike the translator, are more relevant to subordinate dialogism, which, however, involves taking into account the personality of the author of the novel, adoption of his/her position, thoughts, views. This is quite evidence, for example, if we look at the translation done by Olga K.: «live by the foma*» (Vonnegut, 2009: 9) - «живи як фома». This phrase A. Nemirova translated as «живи безпечно» (Vonnegut, 2016: 9). In another example we have the translation having been done by Galyna V.: "[it] was about the end of the world in the year 2000 ..." (Vonnegut, 2009: 23) - "[ие] було про кінець світу в 2000 роиі ...»; this phrase A. Nemirova translated as «роман описував кінець світу в 2000 poụi» (Vonnegut, 2016: 25).

Thus, the infinite multiplicity of meanings of a novel is conditioned by the total symbolic textual nature. The task of the reader, first and foremost, is to get into the whole semantic structure of the novel, to begin the process of providing the text with its subjective meaning. Of course, it is important to explore ways of meaning-making in the global intertextual space. This does not imply finding only one common sense, even one of all possible meanings. The main purpose of the reader should be a creative thinking process, a process of constructive 
imagination, which allows to grasp the multiple meanings of the text, the openness of the processes of providing meanings into the multicultural space of world civilization.

\section{References}

Aleksandrov, A.A., Memetova, K.S., \& Stankevich, L.N. (2020). Referent's Lexical Frequency Predicts Mismatch Negativity Responses to New Words Following Semantic Training. Journal of Psycholinguistic Research, 49, 187-198. https:// doi.org/10.1007/s10936-019-09678-3

Athanasopoulos, P., Bylund, E., Montero-Melis, G., et al. (2015). Two languages, two minds. Psychological Science, 26(4), 518-526. https://doi. org/10.1177/0956797614567509

Bakhtin, M.M. (1975). Problemy soderzhanija, materiala $i$ formy $v$ slovesnom hudozhestvennom tvorchestve. Voprosy literatury $i$ jestetiki [The problems of content, material and form in verbal art. Questions of literature and aesthetics]. Moscow: Science [in Russian].

Bondarenko, Yu.I. (2016). Metody navchannia v konteksti zahalno dydaktychnoi ta metodyko-literaturnoi struktury uroku [Teaching methods in the context of general didactic and methodological and literary structure of the lesson]. Naukovi zapysky NDU im. M.Hoholia. Psykholoho-pedahohichni nauky - Scientific notes of NDU named after M. Gogol. Psychological and Pedagogical sciences, 4, 5863 [in Ukrainian].

Boroditsky, L. (2001). Does language shape thought? English and Mandarin speakers' conceptions of time. Cognitive Psychology, 43, 1-22. https://doi.org/10.1006/ cogp. 2001.0748

Boroditsky, L. (2011). How languages construct time. In S. Dehaene \& E. Brannon (Eds.), Space, time and number in the brain: Searching for the foundations of mathematical thought (pp. 333-342). London: Academic Press. https://doi. org/10.1016/B978-0-12-385948-8.00020-7

Bowerman, M., \& Levinson, S. (2001). Language acquisition and conceptual development. Cambridge: Cambridge University Press. https://doi.org/10.1017/ CBO9780511620669

Brudnyi, A.A. (1975). Ponimanie kak komponent psihologii chtenija [Understanding as a component of the Psychology of Reading]. Problemy sociologii i psihologii chtenija - Problems of Sociology and Psychology of Reading (pp. 162-172). Moscow: Book [in Russian].

Delong, K.A., Troyer, M., \& Kutas, M. (2014). Pre-processing in sentence comprehension: Sensitivity to likely upcoming meaning and structure. Language and Linguistics Compass, 8(12), 631-645. https://doi.org/10.1111/lnc3.12093

Dickens, Ch. (1991). The Adventures of Oliver Twist. London. Random House.

Elahi Shirvan, M., Khajavy, G.H., \& MacIntyre, P.D. (2019). A Meta-analysis of L2 Willingness to Communicate and Its Three High-Evidence Correlates. Journal of Psycholinguistic Research, 48, 1241-1267. https://doi.org/10.1007/s10936-01909656-9

Feinmann, D. (2020). Language and Thought in the Motion Domain: Methodological Considerations and New Empirical Evidence. Journal of Psycholinguistic Research, 49, 1-29. https://doi.org/10.1007/s10936-019-09668-5 
Fodor, J.A. (1975). The language of thought. Cambridge, MA: Harvard University Press.

Fuhrman, O., \& Boroditsky, L. (2010). Cross-cultural differences in mental representations of time: Evidence from an implicit nonlinguistic task. Cognitive Science, 34(8), 1430-1451. https://doi.org/10.1111/j.1551-6709.2010.01105.x

Gennari, S.P., Sloman, S.A., Malt, B.C., \& Fitch, T.W. (2002). Motion events in language and cognition. Cognition, 83, 49-79. https://doi.org/10.1016/S00100277(01)00166-4

Gleitman, L., \& Papafragou, A. (2005). Language and thought. In K.J. Holyoak \& B. Morrison (Eds.), Cambridge handbook of thinking and reasoning (pp. 63-89). Cambridge: Cambridge University Press.

Hu, Z., \& Liu, H. (2019). The Affective Meaning of Words is Constrained by the Conceptual Meaning. Journal of Psycholinguistic Research, 48, 1377-1390. https://doi.org/10.1007/s10936-019-09663-w

Hugo, V. (2003). Sobor Parizhskoj Bogomateri [Notre-Dame de Paris] (Trans. French). Moscow: NF «Pushkin Library», LLC «Publishing House AST» [in Russian].

Jackendoff, R. (1983). Semantics and cognition. Cambridge, MA: MIT Press.

Jiang, M., Jong, M., \& Tse, C. (2020). Examining the Effect of Semantic Relatedness on the Acquisition of English Collocations. Journal of Psycholinguistic Research, 49, 199-222. https://doi.org/10.1007/s10936-019-09680-9

Kalmykova, L.A., \& Kalmykov, G.V. (2015). Konceptualnye podhody k sovershenstvovaniju psihologicheskoj podgotovki budushhih pedagogov [Conceptual approaches of improving the psychological training of future teachers]. Materialy konferencii «Pedagogika $i$ psihologija kak resurs razvitija sovremennogo obshhestva: problemy setevogo vzaimodejstvija $v$ inkljuzivnom obrazovanii» - The issues of the conference "Pedagogy and Psychology as a Resource of the Development of Contemporary Society: Problems of Network Interaction in Inclusive Education» (Ryazan, October 8-10 ${ }^{\text {th }}$, 2015) (pp. 238243). Ryazan [in Russian].

Kalmykova, L.O. (2016). Rozvytok komunikatyvnoi osobystosti v umovakh smyslovoi vzaiemodii [The development of Communicative Person in conditions of semantic interaction]. Pereyaslav-Khmelnitskyi: Publishing House «A Word» [in Ukrainian].

Karpenko, Z.S. (2009). Aksiolohichna psykholohiia osobystosti [Axiological Psychology of the Person]. Ivano-Frankivsk: Lily - NV [in Ukrainian].

Kesebir, S. (2017). Word order denotes relevance differences: The case of conjoined phrases with lexical gender. Journal of Personality and Social Psychology, 113(2), 262-279. https://doi.org/10.1037/pspi0000094

Kukharenko, V.A. (2004). Interpretatsiia tekstu [Text's interpretation]. Vinnytsia: A NEW BOOK [in Ukrainian].

Kuperberg, G.R., \& Jaeger, T.F. (2015). What do we mean by prediction in language comprehension? Language, Cognition and Neuroscience, 31(1), 32-59. https:// doi.org/10.1080/23273798.2015.1102299

Lucy, J. (1996). The scope of linguistic relativity: An analysis and review of empirical research. In J. Gumperz \& S. Levinson (Eds.), Rethinking linguistic relativity (pp. 37-69). Cambridge: Cambridge University Press.

Lucy, J. (2010). Language structure, lexical meaning and cognition: Whorf and Vygotsky revisited. In B.C. Malt \& P. Wolff (Eds.), Words and the mind: How words capture human experience (pp. 266-286). Oxford: Oxford University Press. https://doi.org/10.1093/acprof:oso/9780195311129.003.0014 
Myachykov, A., Garrod, S., \& Scheepers, C. (2012). Determinants of structural choice in visually situated sentence production. Acta Psychologica, 141(3), 304-315. https://doi.org/10.1016/j.actpsy.2012.09.006

Papafragou, A., Hulbert, J. \& Trueswell, J. (2008). Does language guide event perception? Evidence from eye movements. Cognition, 108, 155-184. https://doi. org/10.1016/j.cognition.2008.02.007

Rubskyi, V.M. (2019). Communication levels of the individuals. Topical issues of philosophical anthropology, 16, 24-32. https://doi.org/10.15802/ampr. v0i16.150217

Shtyrov, Y., Kirsanov, A., \& Shcherbakova, O. (2019). Explicitly slow, implicitly fast, or the other way around? Brain mechanisms for word acquisition. Frontiers in Human Neuroscience, 13, 116. https://doi.org/10.3389/fnhum.2019.00116

Stutterheim, von C., \& Nüse, R. (2003). Processes of conceptualization in language production: Language-specific perspectives and event construal. Linguistics, 41, 851-881. https://doi.org/10.1515/ling.2003.028

Vonnegut, K. (2009). Cat's Cradle. New-York: Random House Publishing Group.

Vonnegut, K. (2016). Kolyska dlia kishky [Cat's Cradle]. (Trans. English by A. Nemirova). Kharkiv: CSD [in Ukrainian].

Voronkova, N. (2020). Mozhlyvosti zastosuvannia riznykh vydiv interpretatsii khudozhnoho tekstu pry navchanni inozemnii movi [The possibilities of using different types of interpretation of a novel in teaching a foreign language]. Naukovi zapysky. Seriia: filolohichni nauky - Proceedings. Series: Philological Sciences, 89(2), 274-279 [in Ukrainian].

Wallentin, M., Rocca, R., \& Stroustrup, S. (2019). Grammar, Gender and Demonstratives in Lateralized Imagery for Sentences. Journal of Psycholinguistic Research, 48, 843-858. https://doi.org/10.1007/s10936-019-09634-1

Wolff, P., \& Holmes, K.J. (2011). Linguistic relativity. Wiley Interdisciplinary Reviews: Cognitive Science, 2, 253-265. https://doi.org/10.1002/wcs.104

Khmil, V.V., \& Popovych, I.S. (2019). Philosophical and psychological dimensions of social expectations of personality. Anthropological measurements of Philosophical Research, 16, 55-56. https://doi.org/10.15802/ampr.v0i16.187540

\begin{abstract}
АНОТАЦІЯ
Mета статті - виявити компоненти діяльності учнів з читання художніх творів на уроках світової та англійської літератури в закладах середньої освіти; запропонувати такі типи діалогізму, які сприятимуть розумінню творів художньої літератури учнями; описати результати проведеного пілотного дослідження, яке було проведено у вересні-грудні 2019 року в закладі середньої освіти № 15 м. Рівного на уроках англійської літератури з метою аналізу типів діалогізму в процесі читання та розуміння художніх творів учнями.
\end{abstract}

Методи та методичний інструментарій. У дослідженні використано такі методи: методи цілісного аналізу тексту, проблемно-тематичного та порівняльного аналізу (Bondarenko, 2016); описовий метод, метод послідовного аналізу, метод синтаксичної трансрормації текстового матеріалу (Voronkova, 2020). 
Результати дослідження. Враховуючи особливості учнів старшого шкільного віку, ми виділили три основні компоненти діяльності старшокласників з читання літературних творів на уроках Зарубіжної та Англійської літератури в закладах середньої освіти, а саме: (1). Когнітивний компонент, що має в своїй структурі: (а) змістове читання; (б) інтерпретативне читання; (в) смислове читання. (2). Комунікативний компонент. (3). Суб'єктно-орієнтований компонент. Ми сформулювали такі види діалогізму: (1). Субординативний діалогізм, який передбачає урахування особистістю суб'єктності співрозмовника, яким у даному разі виступає суб'єкт літературного твору, тобто його позиції, думок, поглядів. (2). Координативний діалогізм, який на відміну від субординативного орієнтується не так на особистісний аспект, як на процесуальність взаємодії в широкому розумінні цього слова. (3). Особистісно-рефлексивний діалогізм є найбільш глибоким за змістом $з$ огляду на розуміння партнера у спілкуванні.

Висновки. Доведено, що старшокласники, як правило, орієнтуються на координативний діалогізм у розумінні прочитаного літературного твору, адже для них $\epsilon$, передусім, досить важливою процесуальність взаємодії учасників квазіспілкування, якими постають сам учень та автор твору. Для того, щоб актуалізувати субординативний та особистісно-рефлексивний діалогізм, на нашу думку, старшокласників слід залучати до перекладу художніх творів, написаних іноземною мовою (йдеться про переклад з іноземної мови на рідну).

Ключові слова: розуміння творів художньої літератури, фасилітація розуміння творів художньої літератури, читацька діяльність, когнітивний компонент, комунікативний компонент, суб'єктно-орієнтований компонент, субординативний діалогізм, координативний діалогізм, особистіснорефлексивний діалогізм.

\section{Михальчук Наталья \& Хупавцева Наталья. Фасилитация понимания старшеклассниками литературных произведений как психолингвистическая проблема}

\section{АНОТАЦИЯ}

Цель статьи - определить компоненты деятельности учащихся по чтению художественных произведений на уроках мировой и английской литературы в учреждениях среднего образования; предложить типы диалогизма, способствующие пониманию учащимися произведений художественной литературы; описать результаты проведённого пилотного исследования, организованного в сентябре-декабре 2019 года в школе № 15 г. Ровно на уроках английской литературы с целью анализа типов диалогизма в процессе чтения и понимания учащимися художественных произведений.

Методы и методический инструментарий исследования: целостный анализ текста, проблемно-тематический и сравнительный анализ (Bondarenko, 2016); описательный метод, метод последовательного анализа, метод синтаксических трансформаций текстового материала (Voronkova, 2020). 
Результаты исследования. Учитывая особенности учащихся старшего школьного возраста, были выделены три основных компонента деятельности старшеклассников по чтению литературных произведений на уроках зарубежной и английской литературы в учреждениях среднего образования, а именно: (1). Когнитивный компонент, имеющий в своей структуре: (а) содержательное чтение; (б) интерпретативное чтение; (в) смысловое чтение. (2). Коммуникативный компонент. (3). Субъектно-ориентированный компонент. Сформулированы такие виды диалогизма, раскрыто их содержание: (1). Субординативный диалогизм, который предусматривает учёт личностью субъектности собеседника, которым в данном случае выступает субъект литературного произведения, то есть его позиции, мыслей, взглядов. (2). Координативный диалогизм, который в отличие от субординативного ориентируется не столько на личностный аспект, как на процессуальность взаимодействия в широком смысле этого слова. (3). Личностно-рефллексивный диалогизм, который является наиболее глубоким по содержанию, учитывая понимание партнера по общению.

Выводы. Доказано, что старшеклассники, как правило, ориентируются на координативный диалогизм в понимании прочитанного литературного произведения, ведь для них, прежде всего, достаточно важной является процессуальность взаимодействия участников квазиобщения, которыми являются сам ученик и автор произведения. Показано, что для того, чтобы актуализировать субординативный и личностно-рефлексивный диалогизм, старшеклассникам необходимо давать задания по художественному переводу произведений, написанных на иностранном языке (речь идёт о переводе с иностранного языка на родной).

Ключевые слова: понимание произведений художественной литературы, фасилитация понимания произведений художественной литературы, читательская деятельность, когнитивный компонент, коммуникативный компонент, субъектно-ориентированный компонент, субординативный диалогизм, координативный диалогизм, личностно-рефлексивный диалогизм. 